\title{
Prevention and management of stroke in sickle cell disease
}

\author{
Y. Kilinç \\ Çukurova University, Faculty of Medicine, Department of Pediatric Hematology, Balcalı, Adana, \\ Turkey
}

\begin{abstract}
Sickle Cell Disease(SCD) is one of the most common hemoglobinopathies in the world which causes stroke. The management of stroke depends on the manifestations and the age of the patient. Especially in childhood, anatomic and physiological abnormalities of CNS may be a predisposing factors. Stroke mostly affects the distal segments of the Internal Carotid Artery, but also middle and anterior segments of the cerebral arteries are involved. The most important predisposing factors are the arterial malformations, stenosis and obstructions in cranial arteries, generally involving Internal Carotid Artery, frequently Proximal Middle Cerebral or Anterior Cerebral Arteries. After infarcts at brain vessels, most frequent clinical findings are hemiparesis or hemiplegia, impaired speech, focal seizures, gait disturbances. Risk factors for predisposing stroke are prior transient ischemia, baseline $\mathrm{Hb}$ decrease, acute chest sydrome within previous two weeks, systolic blood pressure rises, leucocyte increases. The patient with silent stroke or transient ischemic attacks may be asymptomatic or without neurological symptoms. Neuroimaging abnormalities may be seen without significant clinical findings in children with SCD. We talk about silent stroke if there are neuroradiological abnormalities without clinical findings. Children with silent strokes are more prone to new strokes. If there is a significant stroke a ischemic stroke often present with focal neurological signs and symptoms. If patient is asymptomatic or have suspected stroke, first step may be performance of Transcranial Doppler Ultrasonography (TCD). Children with time-averaged mean velocity (TAMV), measured in Middle Carotid Artery or in distal internal carotid Artery abnormally elevated, defined as TAMV $\geq 200 \mathrm{~cm} / \mathrm{sec}$, have sixfold increase for stroke than those with normal TAMV $\leq 170 \mathrm{~cm} / \mathrm{sec}$. For these patients under the risk of stroke, chronic blood transfusion is recommended for pre-
\end{abstract}

Correspondence: Y. Kılınç, Çukurova University, Faculty of Medicine, Department of Pediatric Hematology, Balcalı, 01330, Adana, Turkey.

Key words: sickle cell disease, stroke prevention.

(C) Copyright Y. Kllınç, 2011

Licensee PAGEPress, Italy

Thalassemia Reports 2011; 1(s2):e25

doi:10.4081/thal.2011.s2.e25

This article is distributed under the terms of the Creative Commons Attribution Noncommercial License (by-nc 3.0) which permits any noncommercial use, distribution, and reproduction in any medium, provided the original author(s) and source are credited.

Parts of this work were presented at the "12th International Conference on Thalassemia and Hemoglobinopathies", Antalya (Turkey), 11-14 May 2011. vention of primary stroke events. Because of high oxygene demand in children, the child with SCD who also has anemia is at particular risk. The management of acute stroke includes to rule out hemorrhage, stabilize vital signs, careful use of hydration and RBCs transfusion. Exchange blood with normal RBCs is mandatory; it will improve tissue perfusion and oxygenation. Long-term management of stroke is directed to prevent recurrences with fluids supplementation, a chronic transfusion programme at least for 6 months with exchange transfusion or erythrocytapheresis for reducing the $\mathrm{HbS}$ under $30 \%$. After 3 years of $\mathrm{HbS}$ levels to be maintained $<30 \%$, the $\mathrm{HbS}$ leveles can be raised safely to less than $50 \%$ if the patient has remained neurologically stable. Indefinite chronic transfusion programme was advised for the patients with abnormal TCD values. Hydroxyurea (HU) is an alternative therapy in reducing TCD values and to try to increase $\mathrm{HbF}$ improving the clinical outcome. Periodical cranial Doppler ultrasound examination and selective red blood cell transfusions ' $d$ be useful for stroke prevention.

\section{Introduction}

Sickle cell disease is one of the causes of major morbidities for brain disease called stroke. Sickle cell disease(SCD) is mostly seen in Çukurova Region in Turkey and haplotype 19 is common..$^{1-5}$ Clinically, two groups of patients are seen: one with a mild clinical courses and no blood transfusion need and the other group with frequent vasooclusive and other crises and frequent RBCs transfusion requirement. ${ }^{6-7}$ In Turkey, especially in the southern parts, HbS syndromes are more frequent than in the other parts of the country. In the Çukurova Region which is called for the cities of Içel, Antiochus, Adana, Maraş the frequency of $\mathrm{HbS}$ differs from $0.5 \%$ to $37 \%$. The patients mostly have haplotype $19 \%{ }^{5}$ They are white, have mild and severe courses and also suffers from cerebrovascular accidents about $5 \% .^{8}$

The sickled red blood cells forces the shear pressure of the vessel endothelium, damages the surface and causes to the predisposes occlusion of the vessel. By means of leukocytes and cytokines of cellular adhesion, occlusion, ischemia or infarcts, sometimes life threatening events, superpose. ${ }^{9}$ In accordance with a population statistics, death from SCD is $12 \%$ and SCD is the forth cause in all deaths. ${ }^{10}$ The predisposing factors of stroke in SCD are pneumonia, aplastic crises, viral disease, painfull crises, priapism and dehydratation. Higher leucocyte counts accounts as a risk factor for stroke in SCD patients. Because leukocytes are large, porly deformable, and tend to adhere to endothelium, all characteristics may influence rheological features and blood flow. ${ }^{11}$ More than $50 \%$ of the cases live beyond 50 years. Most of the deaths are not due to the result of chronic organ failure but as a result of acute painfull crisis, chest syndrome or from the stroke (Figure 1).

Sickle Cell Disease(SCD) is one of the most common hemoglobinopathies in the world which causes stroke by the physiopathologi- 
cal events beginning with vasculopathy in circulating blood. It is seen as homozygous status as sickle cell anemia or in double heterozygosity with $\beta^{0}$-thalassemia $\left(\mathrm{S} / \beta^{0}\right)$; with $\mathrm{HbE}(\mathrm{S} / \mathrm{E})$, etc. The stroke is the most troublesome complication of sickle cell anemia.The management of stroke depends on the manifestations and age of the patient. When the oxygene supply to the brain is insufficient, brain dysfunction occurs, this is called as stroke. As a result, ischemia, infarct and tissue necrosis superposes. The Cooperative Study of Sickle Cell Disease showed that stroke is four times prevalent in homozygous SS (SCD) patients than the other SCD syndromes and it is about $0.5 \%$ to $1.0 \%$ in children. ${ }^{2}$ Especially in childhood, anatomic and physiological abnormalities of CNS may be a predisposing factor even if they seem to be normal neurologically. ${ }^{13}$ Although, mostly, it affects the distal segments of the Internal Carotid Artery, also middle and anterior segments of the cerebral arteries are involved. The presence of cerebral infarction with transcranial Doppler ultrasound is seen as a high risk factor for stroke. In childhood, about $7 \%$ of the acute brain infarcts result with bad outcome. In first 20 years of life, the incidence of stroke is about $0.7 \%$, but it reaches to peak values between 5 -10 years of life because of high flow rate in brain and vulnerability of changes of endothelium in this age group. ${ }^{14}$. In Çukurova Region, the incidence for 25 years follow-up of 320 patients is $5.0 \% .{ }^{6}$ Stroke may be the only event or coincides with pneumoniae, aplastic crises, viral diseases, painfull crises, priapism and dehydratation. ${ }^{15}$ The most important predisposing factors are the arterial malformations, stenosis and obstructions in cranial arteries generally involving Internal Carotid Artery, frequently Proximal Middle Cerebral or Anterior Cerebral Arteries. The damaged endotel shows intimal thickening and smooth muscles poliferate. The vascular lesions resulte with narrowing or obliteration of the lumen due to acute infarction at damaged vessels. ${ }^{16-19}$

Most SCD patiients who develop focal motor symptoms of stroke recover with no

obvious motor deficits. Overall, cerebrovascular disorders and stroke are major complications in SCd which deteriorate the clinical course, quality of life, and mortality rate in people with SCD. The phenotypic variations in SCD children is dependent to the functions of regulatory genes. In addition to this, the presence of the story with stroke in the past history of the family means genetic factors play some roles in occurence of stroke.

\section{The Clinical findings}

After infarcts at brain vessels most frequent clinical findings are hemiparesis or hemiplegia, impaired speech, focal seizures, gait disturbances. At the same time behavioral and cognitive disturbances may be seen. If stroke is with bleeding, sudden severe headache, sometimes neck pain, vertigo, syncope, nistagmus, ptosis, meningismus and photofobia may be seen. ${ }^{7}$ Risk factors for predisposing stroke are prior transient ischemia, baseline $\mathrm{Hb}$ decrease, acute chest sydrome within previous two weeks, systolic blood pressure rises, leucocyte increases. ${ }^{20}$

\section{Diagnosis}

The patient with silent stroke or transient ischemic attack may be asymptomatic or

without neurological symptoms. Neuroimaging abnormalities may be seen without significant clinical findings in children with SCD. If there are neuroradiological abnormalities without clinical findings, it is recognized as silent stroke. The children with silent strokes are more prone to new strokes than the children with physiologically normal. The silent strokes are located mostly in Frontal lobe (border zone strokes). The cognitive processes are more disordered in the children with silent stroke. ${ }^{21}$

If there is a significant stroke, neurological findings may be associated with clinical outcome. Ischemic stroke often presents with focal signs and symptoms especially hemiparesis, hemisensory deficits and complaints, focal seizures or visual disturbances. Severe headache and altered level of consciousness are more typical for intracranial hemorrhage. Bilateral hemiparesis is uncommon in SCD because of the blood supply in brainstem which is less affected by occlusive vasculopathy than carotid systems. ${ }^{22}$ The death may be the result of hemorrhagic stroke, but is is very rare after ischemic stroke.

If patient is asymptomatic or have a suspected stroke, first step may be performance of Transcranial Doppler Ultrasonography (TCD). Children with time-averaged mean velocity (TAMV), measured in Middle Carotid Artery or in distal internal carotid Artery, elevated,

\section{Endothelian injury}

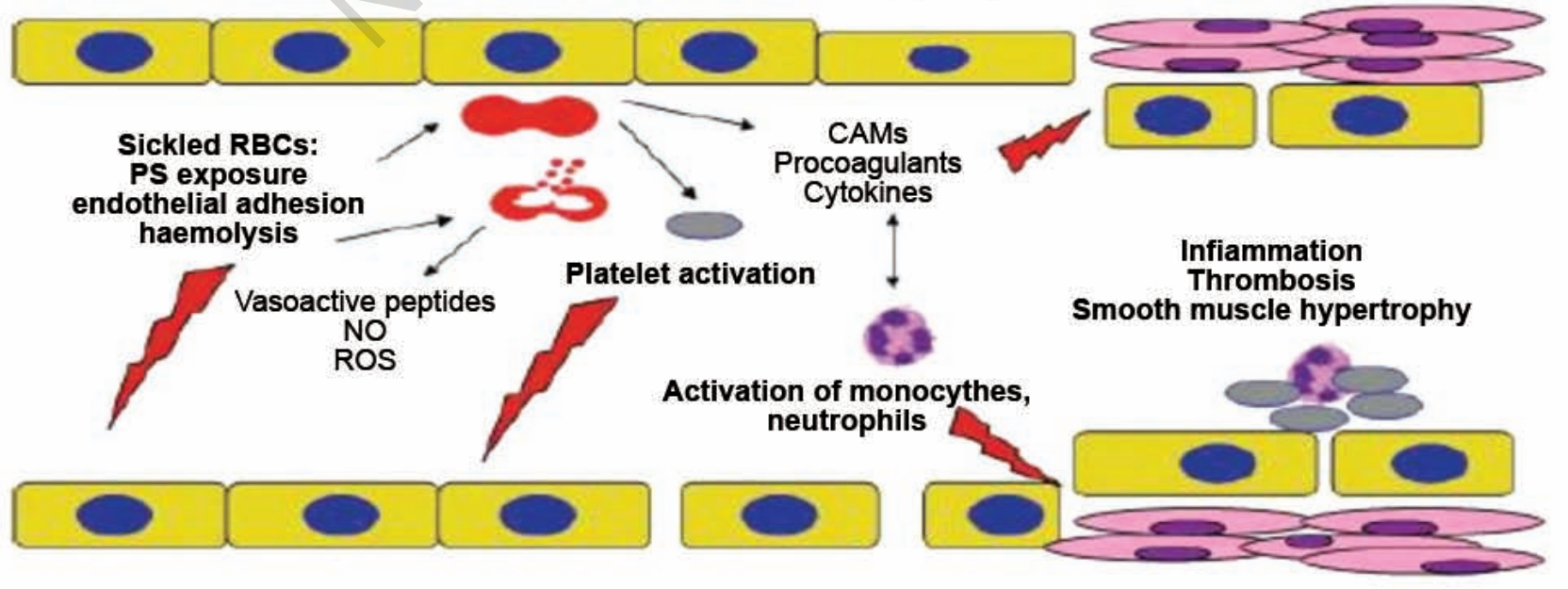

Figure 1. 


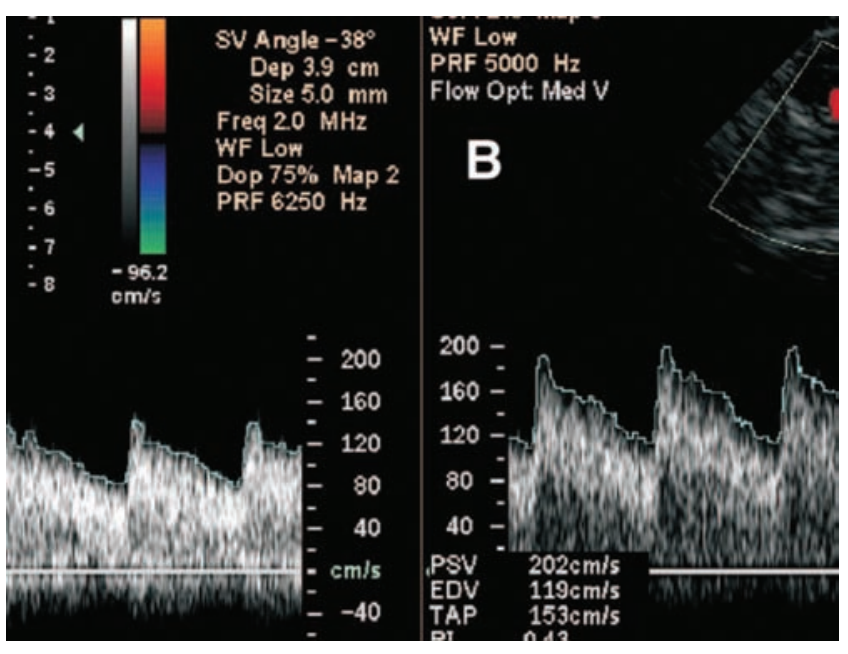

Figure 2. Transcranial doppler ultrasonography. Normal blood velocity at left side, and increased blood velocity at right side.

defined as $\mathrm{TAMV} \geq 200 \mathrm{~cm} / \mathrm{sec}$, have a sixfold increase for stroke than those with normal TAMV $\leq 170 \mathrm{~cm} / \mathrm{sec}^{23,24}$ For these patients under the risk of stroke, chronic blood transfusion is recommended for prevention of primary stroke events. ${ }^{25}$ Therapy should be considered also for the prevention of conversion to abnormal TCD velocities. The early estimation of stroke risk in SCD patients is possible with TCD. ${ }^{24,26-27}$ The rates of primary stroke have been decreased since the implementation of comprehensive TCD screening. ${ }^{28,29}$ Because of high oxygene demand in children, the child with SCD who also has anemia is at particular risk. CBC, ISCs, retic. count, HbF level and peripheral blood smear must be performed. The diagnostic approach is done with TCD (trans cranial doppler), CT(computerized tomography), MRI (magnetic resonance imaging), MRA (magmetic resonance angiography) and cerebral arteriography. The indication for surgical intervention is based upon MRA (Figure 2).

\section{Treatment}

The management of acute stroke includes rule out hemorrhage, stabilization of vital signs, careful use of hydration and RBCs transfusion. SCD stroke patients are generally anemic, correction of anemia. Exchange blood with normal RBCs is mandatory;it will improve tissue perfusion and oxygenation, reversing tissue damage is the goal of early therapy for stroke. Long-term management of stroke is directed to prevent recurrences of strokes in SCD patiets. In treatment, fluid supplementation, chronic transfusion programme at least for 6 months with exchange transfusion or erythrocytapheresis for reducing the $\mathrm{HbS}$ under 30\%. ${ }^{26}$ Both chronic transfusion and Hydroxurea (Hydrea) should be considered after stroke. ${ }^{22}$ After 3 years of $\mathrm{HbS}$ levels to be maintained can be raised to safely to less than $50 \%$ if the patient has remained neurologically stable. ${ }^{31-33}$ Transfusions were effective in the original STOP trial, ${ }^{26}$ but because of discontinuation of chronic transfusion in patients with abnormal TCD velocities resulted in returning of velocities into the abnormal range of stroke. ${ }^{27}$ Indefinite chronic transfusion programme was advised for the patients with abnormal TCD values. Hydroxyurea(HU) therapy is an alternative therapy in reducing TCD values form abnormal to normal values. HU should be given to increase $\mathrm{HbF}^{30,34} \mathrm{HU}$ enhances the $\mathrm{HbF}$ production and may improve clinical outcome. HYDREA(Hydroxyurea) increases fetal hemoglobin synthesis but limits the synthesis ability of bone marrow.
Because of the decrease especially of the granulopoiesis, the granulocyte and platelet counts must be performed in 2 weeks intervals. The effect of HYDREA will appear after months, so the patients must be followed carefully. ${ }^{35}$

In selected cases, stem cell transplantation (SCT) will be lifesaving. ${ }^{36,37}$ Stroke could be prevented by periodical cranial Doppler ultrasound examination and selective red blood cell transfusions are the first steps for the prevention of stroke. ${ }^{10}$

In the last several decades, teharapeutic approach for acute vasoocclusion episodes in SCD narcotic analgesics, i,e, morphine, as well as oxygene supplementation and fluid as neeeded. As is involved small or large arteries or veins, endothelial dysfunction leads to endotheliopathy and stroke, ending with ischemia, infarct or bleeding.

The gene replacement or gene addition therapies are tried in transgenic Mouse models but not in human objects. Hox-B4 idrected differentiation of mesodermal progenitors into hematopoietic stem cells is not efective as human cells; therefore additional factors will be required for efficient HSC differentiation. ${ }^{38}$

For perevntion of SCD, the goals of management should be to motivate the pairs to

prenatal diagnosis if both are trait, to educate the people in productive ages and screening programmes, to educate the population, screening before marriages, to educate teenagers in schools.

\section{References}

1. Arcasoy A, Çavdar A, Cin Ş, et al. The incidence of hemoglobinopathies and thalassemia in Turkey. TUBITAK , Pediatrik Hematoloji ve Onkoloji Çalışmalarından, Ankara, Nuray Matbaası, 1978.

2. Altay C, Gürgey A. Distribution of bemoglobinopathies in Turkey. Turk J Pediatr 1986:28:219-229.

3. Özsoylu Ş, Şahinoğlu M. Hemoglobinopathy survey in an Eti-Turk village. Hum Hered 1975;25: 50-59.

4. Kılınç Y, Gürgey A, Kümi M, Altay Ç. The determination of the prevalance of $\alpha$-thalassemia, Glucose-6-phosphate dehydrogenase deficiency and $\mathrm{HbS}$ in cord bloods of the babies born in Adana District. D0ĞA Scientific Journal 1986;10:2,162-167.

5. Alouch JR, Kılınç Y, Aksoy M, Yüreğir GT, Bakioğlu I, Kutlar A, et al. Sickle cell anemia among Eti-türks: hematological, clinical and genetic observations. Brit J Haematol 1986;64:1,45-49.

6. Kümi M, Kılınç Y, Etiz L. Hematological findins in the milder and severe forms of sickle cell disease. Çukurova Univ Tıp Fak Der 1982;7:349-352.

7. Kılınç Y, Kümi M, Etiz L. The rate of hemolysis during asymptomatic period in the mild and severe forms of sickle cell anemia. Çukurova Univ Tıp Fak Derg 1983;8:4,357-360.

8. Kılınç Y, Şaşmaz I, Antmen B, Kozanoğlu HH, Soyupak S, Altunbaşak ş. Stroke in sickle cell anemia in the mid-southern region of Turkey. In "Focus in sikle cell disease", Plasmar RL(Editor), Nova Biomedical Books, New York, 2003;3:59-69.

9. Adams RJ. Neurologic complications . In Embury SH, Hebbel RP, et al(eds): Sickle cell disease: Basic principles and clinical practice. New York, Raven Pres, 1984:589.

10. Turgeon ML. The hemoglobinopathies. In "Clinical hematology: theory and procedures", fourth ed, Lippincott Williams and Wilkins, 2005;13:171-190.

11. Balkaran B, Char G, Morris JS, Thomas PW, Sergeant BE, and Serjeant GR. Stroke in a cohort of patients with homozygous sickle cell disease. J Pediatr 1992;120:360-366.

12. U.S. Department of health and human services. The management of sickle cell disease. National Institutes of Health, National Heart, 
Lung, and blood diseases, division of blood diseases and Resources, fourth ed, 2004,83-94.

13. Powars DL. Management of cerebral vasculopathy in children with sickle cell disease. Br J Haematol 2000;108:666-668.

14. Frempong KO. Stroke in sickle cell disease:demographic, clinical and therapeutic considerations. Semin Hematol 1991;28:213.

15. Nathan DG, and Orkin SH. Sickle cell disease. In "Hematology of infancy and chilhood", WB Saunders Co, Harcourt Brace Jovanovich, Philadelphia,1998;20:768-800.

16. Telen MJ, Ataga KL, Ballas SK. Role of adhesion molecules and vascular endothelium in the pathogenesis of sickle cell disease. Hematology 2007, ASH Education Book, 84-90.

17. Brown MD, Wick TM, Eckman JR. Activation of vascular endothelial cell adhesion molecule expression by sickle blood cells. Pediatr Pathol Mol Med 2001;20:47-72.

18. Wautier JL, Pintighy D, Maclouf J, Wautier MP, Corwazier E, Caen J. Release of prostacyclin after erythrocyte adhesion to cultured vascular endothelium. J Lab Clin Med 1986;107:210-215.

19. Johnson C, and Telen MJ. Adhesion molecules and hydroxyurea in the pathophysiology of sickle cell disease. Hematologica 2008;93:481-492.

20. Adams RJ, Ohenr-Frempong K, and Wang W. Sickle cell and the brain. Hematology 2001, ASH Education Book, 31-46.

21. Dowling MM, Quinn CT, Rogers ZR, and Buchanan GR. Acute cerebral infarction in children with sickle cell anemia. Pediatr Blood Cancer 2010;54:461-464.

22. Stockman JA, Nigro MA, Mischin MM, et al. Occlusion of the large cerebral vessels in sickle cell anemia. N Engl J Med 1972;287:846849.

23. Adams RJ, McKie V, et al. The use of transcranial ultrasonography to predict stroke in sickle cell disease. N Engl J Med 1992;326:605.

24. Adams RJ, McKie VC, Hsu L, et al. Prevention of a first stroke by transfusions in children with sickle cell anemia and abnormal results on trancranial Doppler ultrasonography. New Engl J Med 1998:339:5-11.

25. Hankins JS, Fortner GL, McCarwille MB, et al. The natural history of conditional transcranial Doppler flow velocities in children with sickle cell anemia. British J Haematol 2008:142, 94-99.

26. Adams RJ, Brambilla DJ, Granger S, et al. Stroke and conversion to high risk in children screened with transcranial Doppler ultrasound during the STOP study. Blood 2004;103:3689-3694.

27. Platt 0:Prevention and management of stroke in sickle cell anemia. American Society of Hematology, Education Program Book, 2006:54-62.

28. Fullerton HJ, Adams Rj, Zhao S, and Johnston SC. Declining stroke rates in Californian children with sickle cell disease. Blood 2004;104, 336-339.

29. McCarwille MB, Gooding GS, Fortney G, et al. Evaluation of a comprehensive transcranial Doppler screening programme for children with sickle cell anemia. Pediatric Blood and Cancer. 2008;50:818821.

30. Platt OS, Orkin SH, Dover G, Beardslwey GP, Miller B, Nathan DG. Hudroxyurea enhances fetal hemoglobin production in sickle cell anemia. J Clin Invest 1984;74,652.

31. Frempong KO. Stroke in sickle cell disease:demographic, clinical and therapeutic considerations. Semin Hematol 1991;28:213.

32. Cohen AR, Martin MB, Silbert JH, et al. A modified transfusion program for prevention of stroke in sickle cell disease. Blood 1992;79:1657-1661.

33. Vichinsky EP. Current issues with blood transfusions in sickle cell disease. Semin Hematol 2001;38:14-22.

34. Ferster A, Vermylen C, Cornu G, et al. Hydroxyurea for treatment of severe sickle cell anemia:a pediatric clinical trial. Blood 1996;88:6, 1960-1964.

35. Greenway RA, Ware RE, Thornburg CD. Long-term results using hydroxyurea/phlebotomy for reducing secondary stroke risk in children with sickle cell anemia and iron overload. Am. J. Hematol. 2011;86:357-361.

36. Vermylen C, Fernandez-Robies E, Ninane J Cornu G. Bone marrow transplantation in 5 children with sickle cell anemia. Lancet 1988;1:1427.

37. Vermylen C, Cornu G. Bone marrow transplantation for sickle cell disease. The European Experience. Am J Pediatr Hematol Oncol $1994 ; 16,8$.

38. Townes TM. Gene replacemant therapy for sickle cell disease and other blood disorders. Hematology 2008, ASH Education Book, 193196. 